\title{
PERANCANGAN INTERIOR PUSAT SENI TARI TRADISI SURAKARTA \\ DI SURAKARTA
}

\author{
Sekarwuni \\ Program Studi S-1 Desain Interior \\ Fakultas Seni Rupa dan Desain, Institut Seni Indonesia (ISI) Surakarta \\ Email: sekarwuni@isi-ska.ac.id
}

\begin{abstract}
Interior Design Dance Center in Surakarta Surakarta tradition is dance arts center as a place of artistic dance of the Surakarta tradition. The facilities there include the lobby in which there is the lounge and reception, auditorium, gallery, dance studio, library, fashion makeup training, dormitory, cafeteria, office, health room and room service. These facilities are equipped with infrastructure that makes a traditional dance arts center is the center of Surakarta melengembangkan Surakarta dance arts tradition. The concept used is "SRIKANDI "by lifting the postmodern style. Color is used to give a touch of characteristic heroine for his firm stance, bold and quiet. Circulation space laid out as effectively as possible to facilitate the users. In addition the use of materials, functional furniture and laying sculptures reinforces the theme.
\end{abstract}

Keywords: interior design, art of dance traditions, heroine.

\section{PENDAHULUAN}

Surakarta adalah kota dari pecahan kerajaan Mataram. Pada tanggal, 12 Febuari 1755 terdapat perundingan mengenai pembagian daerah Mataram menjadi Kasunanan Surakarta dan Kasultanan Yogyakarta yang dikenal dengan perjanjian Giyanti. Kemudian disusul dengan pecahnya kerajaan di Surakarta menjadi dua yaitu Kasunanan Surakarta dan Kadipaten Mangkunegaran (1757) dikenal dengan perjanjian Salatiga. ${ }^{1}$

Surakarta dikenal sebagai salah satu inti kebudayaan Jawa karena secara tradisional merupakan salah satu pusat politik dan

1 Sartono kartodirjo, pengantar sejarah baru 1500-1900, (jakarta: gramedia, 1987) hal 42 pengembangan tradisi Jawa. Seni budaya berkaitan langsung dengan kesejahteraan, keindahan, kebijaksanaan, ketentraman, dan pada puncaknya merupakan proses evolusi manusia untuk makin dekat kepada Tuhan Yang Maha Esa. Surakarta menjadi jantung di pulau Jawa sehingga Surakarta memiliki slogan "Solo spirit of Java". Masyarakat di Jawa mengetahui adanya "persaingan" kultural antara Surakarta dan Yogyakarta, Sehingga melahirkan apa yang dikenal sebagai "gaya Surakarta" dan "gaya Yogyakarta" di bidang busana, gerak tarian, seni tatah kulit (wayang), pengolahan batik, gamelan, dan sebagainya.

Keragaman seni yang berada di Surakarta adalah aset pariwisata bagi kota Surakarta. 
Parawisata adalah suatu perjalanan yang dilakukan untuk rekreasi atau liburan. Saat ini banyak kota yang bergantung banyak dari industri parawisata sebagai sumber pajak dan pendapatan untuk perusahaan yang menjual jasa kepada parawisata. Parawisata merupakan unsur utama perkembangan ekonomi untuk kota Surakarta. Pengembangan industri pariwisata adalah salah satu strategi yang dipakai oleh organisasi non-pemerintah untuk mempromosikan wilayah tertentu sebagai daerah wisata untuk meningkatkan perdagangan melalui penjualan barang dan jasa kepada orang lokal. Kota Surakarta adalah kota yang mulai berkembang menjadi kota besar sehingga kebudayaan Surakarta banyak yang tidak dilestarikan karena kemajuan zaman. Seperti kesenian tari tradisi Surakarta saat ini sedikit peminatnya karena kalah dengan budaya luar. Seni tari adalah salah satu kesenian yang sangat memiliki peran terhadap kebudayaan kota Surakarta dan dapat menjadi salah satu aset wisata kota Surakarta.

Seni tari tradisi di Surakarta memiliki sejarah yang panjang hingga mencapai puncaknya menyandang sebutan seni adiluhung. ${ }^{2}$ Konsep adiluhung tidak hanya berlaku dalam masalah estetika, tetapi juga mengandung nilainilai filosofis, religius, edukatif, spiritual, yang mencakup sebagai aspek kehidupan manusia. Setelah pecahnya Surakarta dibagi menjadi dua wilayah sehingga tari tradisi dibagi menjadi dua gaya Surakarta yaitu gaya Kasunanan dan gaya Mangkunegaran. Tari tradisi pada setiap kerajaan merupakan lambang dari kesuksesan dan kebesaran suatu kerajaan. Dua gaya tersebut merupakan kekayaan seni tradisi yang dimiliki kota Surakarta. Walaupun berbeda pada gerak dan kualitas tari tetapi dari teknik, kostum,

2 Adi berarti linuweh, melebihi segalanya atau mempunyai nilai lebih dan luhung yang berarti luhur, tinggi melebihi yang lain dan juga adiluhung sebagai cita-cita yang diharapkan dan di yakini akan terwujud khususnya lewat kesenian. karakter tari dan tata rias masih memiliki kesamaan karena masih dalam satu gaya Surakarta.

Tari Gaya Kasunanan hadir dengan pengaruh India (Hindu, Budha, dan Islam), yang juga banyak diwarnai pemikiran dan konsep keagamaan semakin menampakkan sifat teosentris. ${ }^{3}$ Tari tradisi Gaya Kasunanan memiliki teba atau jangkauan yang lebih berkembang dari pada gaya Mangkunegaran. ${ }^{4}$ Saat ini banyak tari tradisi yang dimiliki Kraton Kasunanan Surakarta dan masih digunakan sebagai acara upacara adat.

Tari Gaya Mangkunegaran adalah gaya tari pecahan dari gaya Kasunanan Surakarta. Karya tari tradisi pertama di Pura Mangkunegaran adalah ciptakan R.M. Sahid yang kemudian bergelar K.G.P.A.A. Mangkunegaran I. Karena R.M. Sahid menganut agama Islam sehingga terdapat beberapa nuansa Islam dalam karya seni ciptaanya. Pura Mangkunegaran saat ini memiliki konsep pemikiran dan pandangan yang disebut Surya Sumirat, yang berarti pancaran sinar matahari dalam memberikan kehidupan jagad raya dengan segala isinya. ${ }^{5}$ Saat ini tari tradisi di Mangkunegaran sering digunakan untuk acara-acara besar di kota Surakarta seperti Solo International Performing Art (SIPA) sebagai pembukaan maupun pengisi acara.

Seni tari adalah kebudayaan yang harus kita jaga dan dilestarikan. Tari tradisi gaya Surakarta memiliki filosofi makna bentuk dan sejarah. Sangat penting pengetahuan tari tradisi yang dapat dipelajari dan dilestarikan kepada

3 Teosentri adalah perpaduan dari local genius, pengaruh agama Hindu, Budha dan Islam (yang kemudian menjadi budaya kejawen) di istana-istana Jawa banyak tampak dalam pemikiran dan konsep kesenian.

5 Wahyu Santosa Prabowo, S.Kar., M.S., dkk. Sejarah Tari Jejak Langkah Tari Di Pura Mangkunegaran, (Surakarta: ISI Press, 2007) hal. 14 
generasi penerusnya. Tari tradisi di Surakarta sering di pentaskan untuk acara-acara besar di Surakarta Solo International Performing Art (SIPA), World Dance Day (WDD), kirab, Solo Batik Carnival (SBC), Jumenengan dll. Banyak penari-penari Surakarta yang berminat dan bersimpati untuk ikut acara-acara pertunjukan tari tradisi di Surakarta. Tetapi di kota Surakarta belum memiliki tempat umum untuk mengembangkan kekayaan seni tari tradisi Surakarta. Untuk peningkatan dan minat seni tari dalam masyarakat secara kualitas dan kuantitas tidak didukung oleh sarana yang memadai. Hanya terdapat beberapa sanggar tari kreasi, sekolah seni tari dan perguruan tinggi seni tari sehingga untuk masyarakat umum belum bisa belajar seni tari tradisi.

Banyak sekali pengetahuan yang dapat dipelajari dari kesenian tari tradisi gaya Surakarta karena kesenian tersebut adalah salah satu kekayaan kebudayaan Surakarta yang memiliki sejarah, tetapi belum ada wadah untuk pemeliharaan dan pelestarian karya-karya seni tari tradisi gaya Surakarta (meliputi gaya Kasunanan dan Mangkunegaran). Permasalahan tidak adanya wadah untuk memelihara, menyelamatkan dan melestarikan kesenian tradisi seni tari secara umum, seperti ilmu gerak tari, busana, tata rias, perlengkapan tari, dokumentasi bersejarah tentang tari tradisi, ilmu-ilmu filosofi bentuk, dan sejarah tari yang dapat menjadi ilmu pengetahuan.

Kurangnya fasilitas yang mewadai apresiasi masyarakat terhadap seni tari baik fasilitas kegiatan pelatihan maupun pertunjukan yang membutuhkan tingkat kuantitas dan kualitas baik. Oleh karena itu diperlukan tempat yang dapat mewadahi kesenian, terutama seni tradisi Surakarta yang tidak hanya menampung kegiatan pelatihan saja atau pertunjukan saja tetapi menampung keduanya yang juga dapat digunakan untuk umum. Memiliki kegunaan se- bagai informasi yang lebih banyak tentang seni tari tradisi Surakarta kepada masyarakat. Yaitu Perencangan Interior Pusat Seni Tari Tradisi Surakarta sebagai tempat yang dapat mewadahi kebutuhan dan kegiatan seni tari tradisi Surakarta. Selain itu dapat menjadi tujuan pariwisata kepada wisatawan lokal maupun internasional untuk datang ke kota Surakarta mengapresiasi karya seni tari Tradisi Surakarta. Karena tari Tradisi Surakarta adalah salah satu aset pariwisata yang dimiliki kota Surakarta. Dengan adanya Pusat Seni Tari di Surakarta untuk membuat penduduk kota Surakarta yang tidak memiliki wadah. Pusat Seni Tari Tradisi Surakarta akan menjadikan sebagai wadah mengembangkan dan mencari mata pencaharian bagi seniman tari untuk tidak pergi mencari pekerjaan di kota lain yang lebih berkembang bahkan di luar negeri. Hingga para seniman tari yang melestarikan seni tradisional tari lebih memilih untuk mengembangkan kesenian tari di daerah lain yang lebih berkembang.

Pusat Seni Tari Tradisi Surakarta dapat dikembangkan menjadi tempat komersil sehingga dapat disewa oleh pihak yang membutuhkan. Pusat Seni Tari Tradisi Surakarta di kelola oleh organisasi dari perkumpulan seni tari sehingga dapat memasarkan dan mengembangkan tempat ini sesuai dengan segala kebutuhan yang dibutuhkan untuk tari. Pusat Seni Tari Tradisi Surakarta untuk edukasi, tempat mewadahi kebutuhan tari, tempat pertunjukan, dan tempat berkembangnya seni tari. Pusat Seni Tari Tradisi Surakarta di Surakarta juga menjadi wadah untuk memberikan lapangan pekerjaan pada seniman tari. Tema dan gaya pada interior pusat seni tari menggunakan ciri khas seni tari dan gaya postmodern agar susana yang tercipta lebih hidup dan seperti menempatkan diri kepada kearifan lokal budaya, juga memberikan kesan elegan, simple dan nyaman. dengan 
Perencangan Interior Perencangan Interior Pusat Seni Tari Tradisi Surakarta diharapkan masyarakat dapat mengenal kembali sejarah alam, sejarah ilmu pengetahuan dan sejarah kebudayaan masa lalu dengan mempelajari ilmu tari dari segala aspek dengan desain interior yang nyaman. Fungsi Perencangan Interior Pusat Seni Tari Tradisi Surakarta adalah sebagai wadah kreatifitas mengekspresikan diri dalam bentuk tarian klasik. Pusat Seni Tari Tradisi Surakarta ini ditujukan untuk umum semua kalangan dan semua umur dapat menggunakan dan menikmati sajian kesenian tari tradisi Surakarta.

Perancangan Interior Pusat Seni Tari Tradisi Surakarta di Surakarta dapat menjadi penelitian ilmiah, sebagai media pendidikan, pembinaan, penerangan dan hiburan, sebagai pusat pengenalan kebudayaan Surakarta, sebagai cermin sejarah dan kebudayaan, sebagai pusat peningkatan apresiasi budaya, serta sebagai objek wisata. Dengan kita mempelajari seni tari tradisi gaya Surakarta kita dapat melestarikan seni budaya yang dimiliki kota Surakarta. Sehingga kesenian tari tradisi tidak hilang apabila kita dapat melestarikanya dan mengajarkan kepada calon-calon penerusnya. Dengan melestarikan tari tradisi gaya Surakarta dapat mengenalkan kepada negara-negara tetangga dengan kesenian budaya yang kita miliki yaitu tari tradisi gaya Surakarta. Jangan sampai kesenian dan kebudayaan yang kita miliki diakui dan direbut oleh negara lain.

Artikel ini dimaksudkan untuk membahas bagaimana merancang interior pusat seni tari tradisi Surakarta yang dapat memfasilitasi dan mengarahkan pengunjung sesuai dengan fungsi dan ergonomi untuk mendapatkan wadah mengengembangkan kesenian tari tradisi. Tujuan berikutnya adalah merancang pusat seni tari tradisi Surakarta dengan tema Srikandi yang dapat memberi kenyamanan, ketenangan, mengurangi ketegangan dan kecemasan pasien saat melakukan perawatan gigi.

\section{PEMBAHASAN}

Pendekatan pemecahan desain merupakan salah satu runtutan proses desain yang tidak boleh ditinggalkan. Proses pendekatan pemecahan desain ini dapat membantu desainer dalam menganalisa dan menemukan pemecahan dari permasalahan yang dihadapi. Seorang desainer harus mampu memberikan solusi ataupun pemecahan masalah terkait desain yang dikerjakan, seperti kenyamanan, keamanan, faktor estetis, dan lain sebagainya.

Perancangan Interior Pusat Seni Tari Tradisi Surakarta di Surakarta ini merupakan salah satu wujud kepedulian terhadap para seniman-seniman tari tradisional di Surakarta. Saat ini kesenian tari tradisi Surakarta hanya sedikit khalayak umum yang mengetahuinya karena tidak terdapat tempat untuk mempelajarinya seperti galery, auditorium dan tempat untuk pelatihan seni tari tradisi Surakarta. Untuk wadah tempat melestarikan kesenian tari tradisi Surakarta. Dengan adanya pusat tari tradisi ini, diharapkan para seniman tetap mampu melestarikan kesenian tari tradisi ditengah maraknya budaya-budaya barat yang masuk ke Indonesia dan mulai mempengaruhi masyarakat Surakarta.

Perancangan Interior Pusat Seni Tari Tradisi Surakarta diharapkan mampu mengakomodasi semua kegiatan yang bertujuan memajukan dan melestarikan seni pertunjukkan seperti kesenian tari tradisi sehingga tidak hanya tetap eksis namun juga dapat dijadikan sebagai sarana promosi pariwisata di kota Surakarta. Maka dalam mewujudkannya diperlukan beberapa pendekatan desain, diantaranya:

\section{Pendekatan Fungsi}


Desain yang baik adalah desain yang memenuhi kebutuhan fungsi. Seiring dengan perkembangan peradapan manusia, fungsi interior memiliki sejuta makna yang harus ditangkap yang selanjutnya dapat diterjemahkan oleh seorang desainer. ${ }^{6}$ Menurut Francis D.K Ching, pendekatan fungsi yang sesuai kriteria meliputi': (a) Pengelompokan furniture yang spesifik aktivitas; (b) Dimensi dan ruang gerak yang dapat dikerjakan; (c) Jarak sosial yang memadai; (d) Privasi visual dan akustik yang memadahi; (e) Fleksibilitas dan adaptabilitas yang memadahi. Oleh karena itu, perencanaan ini haruslah sesuai dengan fungsi yang sesuai dan dapat mengakomodasi aktivitas pengguna di dalamnya. Adapun aktivitas yang dilakukan dalam Pusat Seni Tari Tradisi Surakarta terdiri dari :

a. Pengurus Pengelola Manajemen (manajer, staf, admin, dll), resepsionis, front office, maintenance, chef, security dan office boy. Masing-masing posisi memiliki tugas kerja masing-masing seperti melayani tamu, mengajar, membersihkan dan mengurusi kantor maupun cafe.

b. Seniman/ Pementas/ Pelatih/ Pengiring tari adalah orang-orang yang datang ke tempat ini untuk menampilkan pertunjukkan dan mengajarkan tari tradisi Surakarta.

c. Pengunjung yang datang ke tempat ini dibagi ke dalam kategori, yaitu pengunjung auditorium, mess, galery, studio tari, ruang kostum dan cafeteria.

d. Dari kategori pengunjung tersebut, maka akan disediakan fasilitas-fasilitas yang

6 Sunarmi, Buku Pegangan Kuliah Metodologi Desain (Surakarta: Program Studi Desain Interior Jurusan Seni Rupa, Institut Seni Indonesia, Surakarta, 2008) Hal 46.

7 F.K. D.Ching, Edisi Kedua Desain Interior dengan Ilustrasi, (Jakarta: Indeks,2011) Hal36. dapat menunjang kegiatan masing-masing pengunjung, yaitu :

\section{1) Auditorium}

Auditorium adalah tempat untuk memenuhi kebutuhan pertunjukan seni. Keperluan pengunjung saat berada di auditorium adalah untuk mengapresiasi pertunjukan seni yang dapat menghabiskan banyak waktu saat berada di dalam ruangan. Fasilitas yang disediakan pada auditorium sesuai dengan kebutuhan pengunjung, penampil pertunjukan dan pengurus pertunjukan meliputi panggung, tempat duduk penonton, foyer, toilet, ruang rias, ruang kontrol audio dan pencahayaan. Desain akan dibuat sesuai fungsi dan kegunaan setiap ruang.

2) Galery

Pada ruang galery memiliki kegunaan sebagai tempat untuk memamerkan suatu benda untuk memberikan edukasi dan mengenalkan berbagai karya seni maupun benda bersejarah kepada masyarakat umum. Keperluan pengunjung yang datang di galery adalah mengapresiasi karya seni atau benda bersejarah yang sedang dipamerkan. Dari keperluan pengunjung galery maka diperlukan fasilitas seperti meja display karya, spot lampu untuk memberikan pencahayaan pada karya, papan tulisan untuk memberikan pengertian karya dan ruang servis.

\section{3) Studio latihan}

Studio tari digunakan untuk tempat latihan menari dan mencari ide saat membuat garapan tari. Studio tari digunakan penggunjung untuk berlatih tari dan les menari untuk anakanak hingga dewasa. Fasilitas ruang yang sesuai dengan kegunaan studio tari adalah ruang kaca cermin, ruang ganti, ruang istirahat, tempat alat musik, tempat audio dan tempat duduk untuk pelatih.

4) Mess 
Mess digunakan untuk tempat singgah sementara saat di pusat seni tari tradisi surakarta. Fungsi mess adalah untuk memfasilitasi pengunjung yang menjadi delegasi atau tamu undangan yang berasal jauh dari kota Surakarta, selain itu juga untuk parawisatawan yang ingin menginap. Dari kegunaan mess maka diperlukan fasilitas yaitu kamar tidur, lemari, kamar mandi, kursi santai.

\section{5) Ruang tata rias busana}

Ruang tata rias busana adalah ruang yang digunakan untuk workshop merias dan menggunakan kostum tari tradisi Surakara. Dari fungsi kegunaan ruang tata rias busana maka fasilitas untuk pengunjung dan pengguna adalah ruang kaca rias, gudang kostum dan ruang servis.

\section{6) Ruang kantor}

Kantor merupakan tempat pengorganisasian pada karyawan dan tempat menyimpan dokumen dalam perusahaan. Berfugsi sebagai aktifitas karyawan dalam kantor dan tempat menerima tamu perusahaan. Pemilihan jenis perabotan, penataan, pemilihan warna dan pencahayaan agar dapat mendukung segala aktivitas di dalam ruangan. Pada ruang kantor ini meliputi : ruang tamu, ruang sekertaris, ruang pemimpin, ruang staf, ruang administrasi, ruang istirahat karyawan, gudang dan pantry. Dalam desain ruang akan ditata sesuai dengan kegunaan dan kebutuhan sehingga komunikasi yang terjalin lebih baik.

\section{7) Cafeteria}

Cafeteria adalah tempat yang digunakan untuk beristirahat dan membeli makanan ringan. Disini pengunjung menghabiskan waktu untuk mengobrol dan beristirahat. Menu di cafe cenderung menyediakan makanan ringan berbeda dengan menu pada restoran yang menyediakan makanan berat. Dari perbedaan menu tersebut menjadikan tingkah laku pengunjung memiliki perbedaan yaitu ketika berada di cafe, pengunjung cenderung lebih lama menghabiskan waktu bersantai. Berbeda ketika berada di restoran, pengunjung hanya datang untuk makan tidak untuk berlama - lama dan bersantai. Cafeteria membutuhkan fasilitas seperti meja bar, dapur, meja makan, toilet dan gudang.

\section{Pendekatan Ergonomi}

Pendekatan ergonomi dilakukan untuk mengetahui standartasi berbagai unsur interior yang akan dirancang agar tercipta keamanan dan kenyamanan interior. Ergonomi dan antropometri mempunyai arti penting dalam perancangan desain interior, oleh karena dengan memperhatikan faktor-faktor ergonomi dan antropometri, para pengguna ruang akan mendapatkan produktivitas dan efficiency kerja yang berarti suatu penghematan dalam penggunaan ruang (space).

Ergonomi adalah suatu ilmu yang mempelajari tentang kondisi fisik seseorang dalam melakukan kerja meliputi: kerja fisik, efisiensi kerja, Tenaga yang dikeluarkan, konsumsi kalori, kelelahan, pengorganisasian sistem kerja. Pengertian ergonomi sangat luas dan tidak hanya terbatas pada sisi-sisi fisik semata seperti tersebut di atas, tapi juga meliputi segala hal yang bersangkutan dengan lima indera manusia yaitu: penglihatan, pendengaran, rasa panas/ dingin, penciuman, dan keindahan/kenyamanan. ${ }^{8}$

\section{Pendekatan gaya dan tema}

Pendekatan tema digunakan sebagai acuan desain yang dibuat sesuai dengan gaya dan tema. Gaya adalah dasar desain yang digunakan dalam mendesain interior. Tema berarti pokok pemikiran, ide atau gagasan yang akan dis-

8 Suptandar Pamudji. (1999). Desain Interior: Pengantar merencana interior untuk mahasiswa desain dan arsitektur. Jakarta : Djambatan., hal 51. 
ampaikan. Gaya yang digunakan adalah postmodern karena memiliki ciri-ciri pluraristik, komunikatif, tempat dan sejarah digunakan sebagai komunikasi seperti waktu (dulu, sekarang dan yang akan datang). ${ }^{9}$ Jean Francois Lyotard (1984) dikenal sebagai tokoh yang pertama kali mengenalkan konsep Postmodernisme dalam filsafat. Postmodern adalah pertentangan dari desain modern yang minimalis, simpel dan lugas. Prinsip utama desain ini adalah kompleksitas, kontradiksi, dan cenderung menampilkan sisi yang maksimal dari suatu ruangan. Desain Postmodern selain mempertimbangkan kepraktisan, juga mempertimbangkan sentuhan individu, ornamen, dan nostalgia masa lalu baik berupa gaya-gaya di masa Ancient maupun gaya desain di masa Abad Pertengahan maupun di masa modern. Gaya-gaya masa lalu ini kadang dipadu dan memperlihatkan desain yang bersifat eklektik (perpaduan). Namun demikian Postmodern tidak hanya mencontoh desain-desain masa lalu tersebut, tetapi menampilkannya sesuai dengan perkembangan jaman. Selain Robert Venturi, tokoh lainnya adalah Frank Gehry, Ettpre Sottsass.

Postmodern adalah gaya yang pernah dipopulerkan pada tahun 1970-an dan 1980-an, serta merupakan pertentangan dari desain modern yang minimalis, simpel dan lugas. Prinsip utama desain ini adalah kompleksitas, kontradiksi, dan cenderung menampilkan sisi yang maksimal dari suatu ruangan.

Dengan tema Srikandi diharapkan akan memunculkan desain dengan bentuk dan karakter visual tokoh tarian lakon srikandi dengan gaya postmodern. Melalui pendekatan tema dalam mengolah interior, maka cita rasa ruang dan pengguna memperoleh eksistensinya sesuai dengan bentuk dan karakter visual dari gaya postmodern. Tema yang digunakan adalah Srikandi, tema Srikandi menggunakan 9 Aditya Media 'Postmodernitas dan masa depan peradabanya"(halaman 220-222) bentuk-bentuk ciri khas dan filosofi dari tokoh wayang Srikandi. Srikandi dalam seni tari putri gaya Surakarta akan menjadi elemen pembentuk dan pengisi ruang dengan cara di aplikasikan dan di transformasikan. Srikandi dalam tokoh pewayangan yang sangat terkenal. Srikandi seorang wanita, puteri Raja Drupada dan Permaisuri Gandawati dari negeri Pancala. Meski dikatakan anak Drupada-Gandawati, tapi Srikandi lahir dari api pemujaan Drupada. Waktu tercipta dari api pemujaan itu bayi Srikandi sudah menggendong tabung anak panah dan memegang busur. Dalam perjalanan waktu Srikandi menjadi prajurit handal Pancala dan memperdalam ilmu memanah pada Arjuna, Srikandi jatuh cinta dan keduanya pun menjadi suami isteri. ${ }^{10}$

Srikandi dalam karakter tari gaya Surakarta memiliki ciri khas dalam busana kostum maupun gerakan. Busana Srikandi menggunakan irah-irahan lanyap, sumping, klat bahu, mekak dan srempang warna merah (ciri khas Srikandi), sampur warna biru, slepe, jarik motif $p a-$ rang, endhong, nyenyep, gendewa, perhiasan giwang dan kalung bulan sabit. Setiap busana yang dikenakan oleh Srikandi memiliki filosofi sehingga sampai saat ini busana yang digunakan selalu sama dan tidak di ubah untuk karakter tokoh Srikandi. Dengan tema Srikandi pada pusat seni tari tradisi Surakarta diharapkan dapat memberikan suasana tari dengan mewakili satu tokoh tari dengan mengaplikasi dan mentransformasikan ciri khas tokoh Srikandi sehingga dapat menjadi edukasi untuk pengunjung.

Proses pendekatan estetika pada Perancangan Interior Pusat Tari Seni Tradisi Surakarta di Surakarta di kota Surakarta dititik beratkan kepada bentuk gerak, rias busana dan filosofi tari putri gaya Surakarta dengan lakon Srikandi.

10 Soedarsono, Wayang wong: the state ritual dance drama in the court of Yogyakarta.

(Yogyakarta:gajah mada university press, 1984) hal 25 
Pada pengaplikasian Estetika di tiap sisi ruangan-ruangan Pusat Seni Tari Tradisi Surakarta melibatkan bentuk gerak, rias busana dan filosofi lakon tari srikandi dan menunjukkan citra dari seni tari tradisi gaya Surakarta kemudian diaplikasikan dalam bentuk mebel sampai benda pajang yang berbentuk benda hingga lukisan sekaligus, dengan memulai dari gendewa, nyenyep, kalung bulan sabit, sampai bentuk-bentuk yang menyerupai gerakan tari Srikandi, sehingga menimbulkan kesan seni tari dengan mewakili Srikandi sebagai lakon tari putri tradisi gaya Surakarta. selain itu pengaplikasian dalam hal warna sangat menentukan suasana dalam ruangan.

Warna adalah salah satu elemen penting dalam sebuah interior. Penentuan warna yang tepat sangat penting untuk membangun suasana yang ingin diciptakan dalam ruangan tersebut. ${ }^{11}$ sehingga ruangan yang akan diaplikasikan dalam ruangan Pusat Seni Tari Tradisi Surakarta menggunakan warna merah, biru, emas, coklat, hijau dan putih. Warna merah diambil dari ciri khas busana Srikandi yang melambangkan keberanian dan pantang menyerah sebagai prajurit wanita yang memerangi kejahatan dengan penggunaan warna merah akan memberikan suasana semangat dan berani pada ruangan. coklat membuat suasana terlihat natural, klasik dan eksotis. Identik dengan kematangan usia dan nilai yang tinggi seperti yang terdapat pada benda-benda seni dan antik. Netral, cocok untuk diterapkan pada berbagai ruang. ${ }^{12}$ Warna putih bersifat lembut, feminine dan romantic sehingga memberi kesan tenang dan menyenangkan. ${ }^{13}$ Warna biru kemudian memiliki arti yang luas, dingin, penuh strategi dalam berbisnis.

11 Denny Prawibowo. 2015. Makna Warna Dalam Desain Interior. http://efratainterior.com/makna-warna-dalam-desain-interior/. 13.12 WIB. 03/01/2016 12 Denny Prawibowo, 2015. Makna Warna Dalam Desain Interior. http://efratainterior.com/makna-warna-dalam-desain-interior/. 13.12 WIB. 03/01/2016 13 Prawibowo. 2015. dengan aksen warna emas guna menunjukkan kekuasaan dan kehebatan prajurit wanita, karena warna emas melambangkan kekayaan dan kemakmuran. ${ }^{14}$.

\section{Ide Perancangan}

Ide perancangan pada Perancangan Interior Pusat Seni Tari Tradisi Surakarta menggunakan ide dasar dari pendekatan desain. Dengan ide perancangan melalui pendekatan desain maka akan mengarahkan desain untuk merancang sesuai dengan tujuan pendekatan desain. Dengan pendekatan desain pada ide perancangan akan menjadi patokan untuk mendesain Perancangan Interior Pusat Seni Tari tradisi Surakarta. Ide perancangan pada Perancangan Interior Pusat Seni Tari Tradisi Surakarta menggunakan ide dasar dari pendekatan desain. Dengan ide perancangan melalui pendekatan desain maka akan mengarahkan desain untuk merancang sesuai dengan tujuan pendekatan desain. Dengan pendekatan desain pada ide perancangan akan menjadi patokan untuk mendesain Perancangan Interior Pusat Seni Tari tradisi Surakarta.

Ide perancangan menggunakan pendekatan tema srikandi. Tema adalah suatu gagasan pokok atau ide pikiran tentang suatu hal, salah satunya dalam membuat suatu desain interior yang dapat menjadi daya tarik untuk desain interior. Surakarta adalah kota yang memiliki banyak kesenian dan kebudayaan. Seperti seni tari tradisi gaya Surakarta adalah salah satu kekayaan kesenian yang dimiliki kota Surakarta. Tema yang digunakan adalah Srikandi diharapkan akan memunculkan desain dengan kesan dan wujud bentuk dari ciri khas Srikandi. Pemilihan desain Perancangan interior Pusat Seni tari tradisi Surakarta menggunakan tema Srikandi karena tari tradisional terutama tari putri memiliki tokoh favorit wayang orang yai-

14 Prawibowo. 2015. 
tu srikandi yang menjadi tarian yang memiliki filosofi dan cerita yang sering dijadikan maskot tari putri. Tema Srikandi adalah bentuk keindahan gerak tubuh tari putri gaya Surakarta dan memunculkan kesan dalam keberanian, ketegasan yang mencermikan sikap dari prajurit wanita. Tari Srikandi termasuk dalam jenis tarian Wireng dalam sejarah tari gaya Surakarta. Wireng sebagai salah satu kesenian yang dianggap memiliki kualitas bernilai tinggi dalam masyarakat priyayi yang sering disebut sebagai seni klasik Jawa dalam gaya Surakarta, seperti tari klasik Jawa, karawitan Jawa, dan seni pedhalangan atau seni wayang kulit. ${ }^{15}$

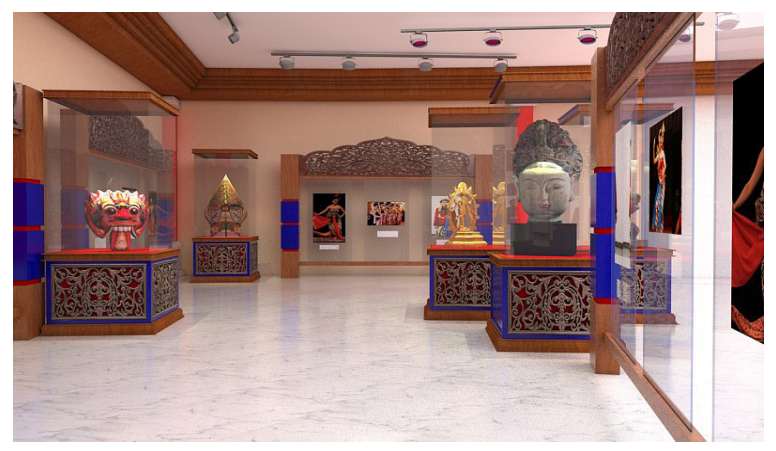

Srikandi adalah tokoh atau lakon dalam pewayangan cerita mahabarata yang menjadi seorang prajurit wanita yang pintar memanah. Wayang kulit merupakan seni yang sangat popular pada masyarakat Jawa sampai sekarang sehingga kebanyakan tari tradisi gaya Surakarta yang berkembang di kerajaan-kerajaan Jawa menggunakan lakon-lakon dari pewayangan. Lakon atau ceritera selalu digunakan sebagai media untuk menggarap masalah-masalah kehidupan yang esensial dalam pertunjukan wayang. Setiap lakon mengandung satu alasan pokok suatu kejadian alam semesta, yang meliputi hubungan orang jawa dengan tatanan alam kodrati, dana alam adikodrati, serta antara dirinya sendiri dengan sesama manusia. ${ }^{16}$

15 Nanik Sri Prihatin. Joged Tradisi Gaya Kasunanan Surakarta, (Surakarta:ISI Press Solo, 2007) hal 29 16 Nanik Sri Prihatin; 2007, 153)
Karater srikandi menurut Edi sedyawati memiliki karakter tari putri endel dengan gerak tegas dan keberanian. Ciri khas pada Srikandi pada busana adalah bermata jaitan, bermuka mendongak, mempunyai hidung mancung bersuara mendencing yang menandakan bahwa dia adalah seorang putri, berssanggul gede, berjamang dengan garuda membelakang, berkalung bulan sabit, sebagian rambutnya polos menjuntai kebelakang dan memakai dodot putren. Dewi Srikandi mempunyai keahlian dalam bidang memanah, keahlian itu diperolehnya setelah berguru kepada raden Arjuna. Pada suatu ketika, Srikandi mendatangi Rarasati untuk belajar memanah karena dilihatnya bahwa Rarasati pernah diajar memanah oleh raden Arjuna. Namun kemudian pada akhirnya, Arjuna yang mengajari Srikandi.

Ide perancangan pada Pusat Seni Tari tradisi Surakarta menggunakan tema Srikandi dengan menggunakan transformasi dan aplikasi dari bentuk gerak, rias busana dan menggunakan filosofi pada lakon tari Srikandi. Berikut adalah transformasi dan aplikasi bentuk gerak dan rias busana tari putri Srikandi pada desain interior yang akan digunakan untuk Perancangan interior Pusat Seni tari tradisi Surakarta.

\section{KELEBIHAN dan KEKURANGAN}

Lantai menggunakan marmer ukuran $100 \times 100 \mathrm{~cm}$. warna marmer putih dengan corak hitam. Lantai menggunakan marmer untuk memberikan kesan elegan dan lebih luas. Sehingga ruang pada gallery tidak terlihat sempit dan dapat dipadukan dengan berbagai motif warna lainya karena bersifat netral.

Dinding menggunakan cat warna coklat muda merk Dulux dan untuk kolom menggunakan cat warna merah merk Dulux dan untuk bagian bawah menggunakan hpl motif kayu. Dengan menggunakan cat warna coklat muda 
akan memberikan kesan lembut. Untuk kolom menggunakan warna merah karena mengambil dari tema Srikandi bahwa warna merah adalah ciri khas dari Srikandi yang menggambarkan semangat dan keberanian kemudian pada bagian bawah kolom menggunakan hpl motif kayu untuk lebih memberikan kesan tradisional.

a. Ceiling menggunakan gypsum dengan finising cat warna putih untuk memberikan kesan luas. Pada list menggunakan kayu.

b. Pengisi ruang :

1. lemari gallery

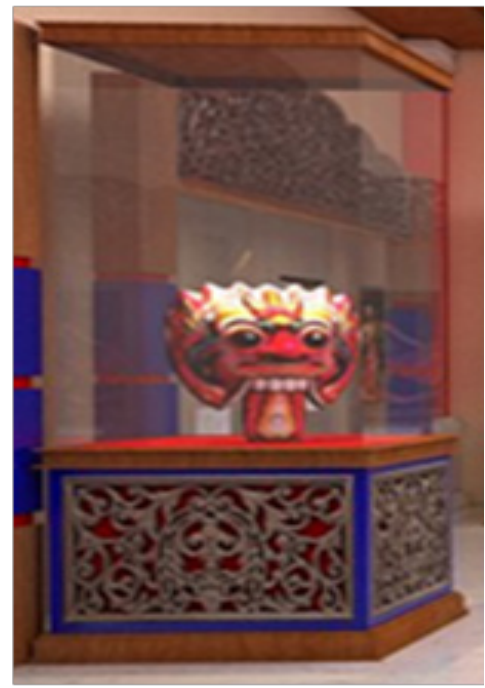

2. Pembatas

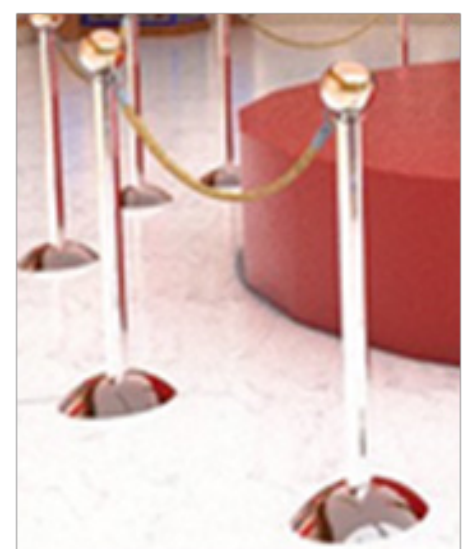

3. Papan display

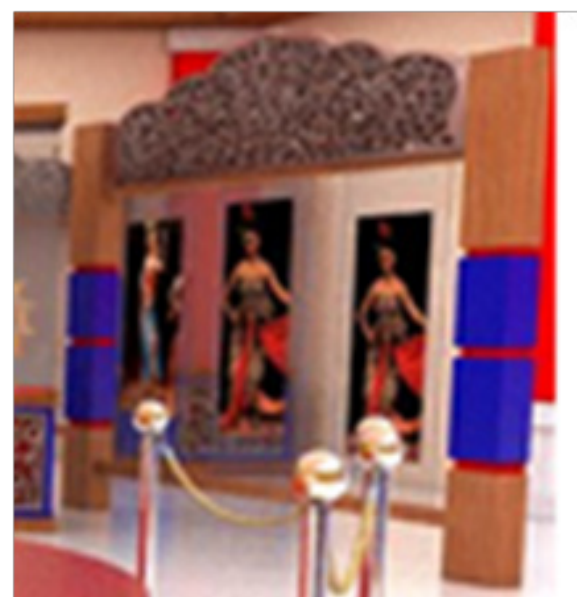

4. Panggung display

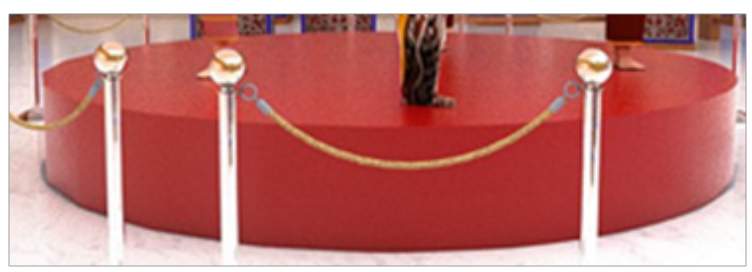

c. Pengkondisian ruang

1. Lampu

- Spot light

- General light

- Downlight

- Mini spot

- Lampu gantung

2. Penghawaan

Menggunakan ac central untuk penghawaan di area gallery

\section{KESIMPULAN}

Di Surakarta, pusat kesenian tari yang dapat menjadi wadah kesenian tari tradisi Surakarta masih jarang dijumpai. Umumnya yang ditemui adalah sekolah tari yang tidak bisa digunakan untuk umum dan sanggar-sanggar tari yang belum memiliki tempat berlatih yang me- 
madai. Hal ini cukup menyulitkan masyarakat ketika mereka ingin berlatih seni tari tradisi Surakarta. Selain sanggar-sanggar tari tradisi di Surkarta yang kurang nyaman dan kurang memadai untuk berlatih menyebabkan banyak orang malas untuk belajar kesenian terutama seni tari tradisi Surakarta. Kenyamanan juga diperlukan oleh para seniman tari, guru tari, dan murid dengan situasi yang kurang nyaman tentunya akan membuat kualitas berlatih menjadi tidak maksimal. Sebuah pusat seni tari tradisi Surakarta hendaknya juga dapat mengedukasi masyarakat akan pentingnya melestarikan kesenian tari tradisi Surakarta yang benar.

Perancangan interior pusat seni tari tradisi Surakarta di Surakarta ini dibuat untuk memberi wadah bagi seniman tari di Surakarta untuk dapat melestarikan kesenian tari dan dapat menjadi tempat mata pencaharian seniman-seniman tari di Surakarta. Sebuah pusat seni tari tradisi Surakarta dengan fasilitas yang memadahi adalah sarana edukasi awal bagi masyarakat. Penawaran fasilitas yang memadahi didukung dengan kebutuhan yang digunakan untuk kesenian seni tari dan nyaman akan membuat orang tertarik untuk dating. Pusat seni tari tradisi Surakarta juga ditujukan sebagai salah satu tempat wisata untuk kota Surakarta karna di Surakarta belum terlalu banyak tempat wisata karna terlalu banyak Mall dan hanya kuliner yang sering dijumpai saat berada di Surakarta.

\section{DAFTAR PUSTAKA}

Aditya Media "Postmodernitas dan Masa Depan Peradabannya", Buku Petunjuk Teknis Tugas Akhir Program Studi Desain Interior, Prodi Desain Interior Jurusan Seni Rupa, Institut Seni Indonesia Surakarta, 2007.
Dr. Nanik sri prihatini., S.Kar., M.Si.,dkk. Ilmu Tari Joged Tradisi Gaya Kasunanan Surakarta, (Surakarta: isi press, 2007)

F. D. K. Ching, Edisi Kedua Desain Interior dengan Ilustrasi, (Jakarta: Indeks,2011)

Ir. Wahyu prastowo, Aliran Post Modern, Diktat Perkembangan Arsitektur 3.

Pamudji Suptandar, Desain Interior (Jakarta: Djambatan, 1999), Sartono kartodirjo, (Jakarta: gramedia, 1987)

Sunarmi, Buku Pegangan Kuliah Metodologi Desain (Surakarta: Program Studi Desain Interior Jurusan Seni Rupa, Institut Seni Indonesia, Surakarta, 2008)

Suptandar, J. Pamudji. Disain Interior. (Jakarta: Djambatan, 1999)

Sunarmi, Ergonomi dan Aplikasinya Pada Kriya, (Surakarta: STSI Surakarta, 2001),

Wahyu Santosa Prabowo, S.Kar., M.S., dkk. Sejarah Tari Jejak Langkah Tari Di Pura Mangkunegaran, (Surakarta: isi press, 2007)

Meri. Sanggar dan Seni Tari. Jakarta, 1987. 12 Desember 2010.

Haukins. Tari Mengolah Tubuh dan Expresi. Jakarta, 1990. 2 January 1990.

Departemen Pendidikan Nasional. Kamus Besar Bahasa Indonesia. Jakarta : PT. Gramedia Pustaka Utama, 2008.

Sedyawati, Edi. Seni Pertunjukan. Yogyakarta : Editions Didier Millet, 1998.

Guntur. Arsitektur dan Interior Nusantara Seri Jawa. Surakarta : UNS Press, 2007, 1 Desember 2007. 